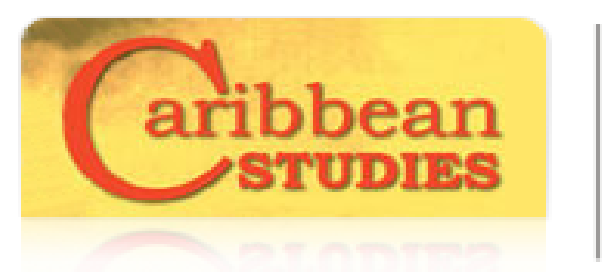

Caribbean Studies

ISSN: 0008-6533

iec.ics@upr.edu

Instituto de Estudios del Caribe

Puerto Rico

Wilson, Leon C.; Wilson, Colwick M.; Johnson, Bridgette M.

Race and Health in Guyana: An Empirical Assessment from Survey Data

Caribbean Studies, vol. 38, núm. 1, enero-junio, 2010, pp. 37-58

Instituto de Estudios del Caribe

San Juan, Puerto Rico

Available in: http://www.redalyc.org/articulo.oa?id=39220687002

How to cite

Complete issue

- More information about this article

Journal's homepage in redalyc.org

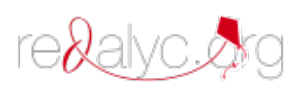

Scientific Information System Network of Scientific Journals from Latin America, the Caribbean, Spain and Portugal Non-profit academic project, developed under the open access initiative 


\title{
RACE AND HEALTH IN GUYANA: AN EMPIRICAL ASSESSMENT FROM SURVEY DATA
}

\author{
Leon C. Wilson \\ Colwick M. Wilson \\ Bridgette M. Johnson
}

\begin{abstract}
This paper examines racial differences in physical health and mental well-being in Guyana, South America: a country with cultural ties to the Caribbean. It explores the complex relationship among race, socioeconomic status and health outcomes which in developed societies continues to be of significant research interest. Utilizing a random probability sample of over 900 adults, the analyses provide information on the general physical and mental health status of this population and examine the differences by racial groups when other factors are controlled. The results indicate significant age-specific racial differences in physical and mental health in Guyana. Higher rates of diabetes, arthritis or rheumatism, back and breathing problems among IndoGuyanese when compared to other groups were noted. Racial differences in physical health were attenuated when gender and educational levels were controlled.
\end{abstract}

Keywords: race, racial differences, mental health, physical health, socio-economic status, socio-demographics characteristics

\section{RESUMEN}

Este artículo examina las diferencias raciales en la salud física y el bienestar mental en Guyana, América del Sur: un país con vínculos culturales con el Caribe. Se explora la relación compleja entre raza, posición socio-económica y los resultados de salud, área de investigación que continúa siendo de interés significativo en las sociedades desarrolladas. Utilizando una muestra de probabilidad aleatoria de más de 900 adultos, los análisis proveen información sobre el estado general de salud física y mental de esta población y examinan las diferencias por grupos raciales cuando otros factores son controlados. Los resultados indican diferencias significativas por edad, específicamente entre razas, en la salud física y mental en Guyana. En comparación con otros grupos, se detectaron tasas altas de diabetes, artritis o reumatismo y problemas respiratorios y de espalda entre los indo-guyaneses. Las diferencias raciales en la salud física disminuyeron cuando el género y los niveles educativos se controlaron. 
Palabras clave: raza, diferencias raciales, salud mental, salud física, posición socioeconómica, características socio-demográficas

\section{RÉSUMÉ}

Cet article examine les différences raciales au point de vue de la santé, physique et du bien-être mental en Guyane, Amérique du Sud : un pays qui a des liens culturels avec la Caraïbe. Il explore la relation complexe entre la race, le statut économique social et les résultats de santé ce qui, dans les societés développées, continue d'être d'un intérêt significatif pour les chercheurs. Utilisant une probabilité d'échantillon aléatoire de plus de 900 adultes, les analyses pourvoient des informations sur le statut de l'état de santé générale physique et mental de cette population et examinent les différences par groupes raciales quand d'autres facteurs sont contrôles. Les résultats indiquent des différences significatives qui sont spécifiques à l'âge et la race au point de vue de la santé physique et mentale en Guyane. On nota des taux plus élevés de diabète, arthrite ou rhumatisme, des problèmes de dos et de respiration chez les Indo Guyanais comparé à d'autres groupes. Les différences raciales au point de vue santé physique furent atténuées quant au sexe et au niveau d'éducation.

Mots-clés: race, différences raciales, santé mentale, santé physique, statut économique social, caractéristiques sociodémographiques

Received: 6 November 2008 Revision received: 16 July 2010 Accepted: 20 July 2010

\section{Introduction}

7 he study of racial differences or racial disparities in physical and mental health continues to be of significant interest to social scientists, medical researchers and policy analysts in the USA and other developed societies. Researchers in these contexts frequently use the terms "differences" and "disparities" interchangeably, but in the strictest sense, racial differences in health outcomes refer to observed frequencies of illnesses or diseases attributable to genetic or physical factors (Carter-Pokras, Baquet 2002). "Disparities," on the other hand, is used to describe differences due to other (mostly social) causes, which, if not present, would result in equal physical and mental health outcomes. In fact, it is suggested that while disparities indicate differences, not all differences are considered disparities (Rathore and Krumolz 2004).

In many developed societies, and especially in the USA, the term "disparities" has become more of a buzzword in policy-oriented research, 
because it implies that generally observed differences in health outcomes derive from inequities in the distribution of resources and life circumstances are due to the social location of various groups within a given population. This paper is about racial "differences" in physical and mental health outcomes in Guyana, a third world country in South America, but which is culturally tied to the Anglophone Caribbean. At times, however, though the term "disparities" is used interchangeably, the paper is more concerned with describing racial differences than identifying the underlying causal mechanisms that may be implicated in explaining any such differences. Since research on this issue in Guyana is scant and emerging, we await a greater body of research that provides focused analyses of the distinctions between differences and disparities and the mechanisms that account for health variations across racial groups. Nonetheless, as we describe these differences, we will examine if they persist when certain critical social-economic and demographic factors are taken into account.

To a large extent in societies such as the USA, race or ethnicity is a maker of significant differences in the distribution of resources and access to health promoting assets (Williams, Lavizzo-Mourey, and Warren 1994). A significant body of research is available on the nature and complexity of the relationships among race, class, and socio-economic factors (Fiscella and Williams 2004). Accordingly, the relationships among race, socio-demographic factors, and health are well established in some research contexts. In general, one of the most compelling conclusions is that while racial differences are evident for certain illnesses and diseases, other social factors are more powerful determinants of health disparities among racial groups in many instances. Specifically, indicators of socioeconomic status (SES) [more often income, education, or occupation and sometimes wealth and assets] are well established as some of the strongest determinants of variations in health, and account for large share of racial differences in health (Williams and Collins 1995).

It is important to note that all of the aforementioned indicators of SES are strongly patterned by race. Thus, the role of SES in health should be interpreted within the framework of known racial differences in SES. Nonetheless, racial differences persist even after controlling for SES for most of the leading markers of health status (Williams and Collins 1995). This suggests that racial differences, independent of SES, uniquely account for differences in health. Race is therefore an important and significant marker for differential exposure and vulnerability to a broad range of disease-producing social factors associated with health status.

The pattern of results for racial differences in physical health is somewhat different from those documented for mental health in the United States. That is, researchers have consistently found over time, 
across different methodologies, and for multiple indicators of health status, large black-white differences in physical health (Braithwaite and Taylor 2001; Krieger 1987; LaVeist 2000). This body of literature clearly indicates that despite general improvements in health during the twentieth century, blacks in the USA continue to report significantly higher levels of ill health compared to whites. In fact, there is some indication that the black-white gap for multiple indicators of physical health has widened (Williams 1999; Williams and Collins 1995). However, while the findings of black-white differences in physical health have been consistent over time, no uniform or conclusive pattern has emerged in the study of black-white differences in mental health in the United States.

Mental health is a multidimensional construct with multiple indicators, each of which captures varying aspects of people's lives. This is especially salient for comparisons across racial groups in the United States or in other social contexts where race is an important marker of status in the society. Social groups experience the world in different ways largely due to the social inequities that are associated with the relative location and position of minority and majority populations. That is, the experiences and interpretations of the circumstances of life vary across racial groups and may have implications for particular measures of mental health status (Wilson and Williams 2004). As such, the research literature on racial differences in mental health in the United States reveals an inconsistent pattern of findings with studies varying in the extent to which differences in reported levels of mental health exist between blacks and whites (Neighbors and Williams 2001). Thus, the complex relationship between racial status and health should be examined across multiple measures of both physical and mental health outcomes.

In this paper we report on self-reported health, impairment because of illness, lifetime and recent (one-year) incidents of chronic illness. We also examine mental health with specific emphasis on depressive symptomology and life satisfaction and the extent to which these outcomes vary by racial groups. We investigate what obtains in the Guyana context since it is unclear whether these patterns of racial differences in health as observed in other social contexts operate similarly (or differently) in Guyana.

\section{Disparity Research in the Caribbean}

While disparity studies specific to Guyana are almost non-existent, in the larger Caribbean context and especially in the Latin America, there is an increasing number of studies that address differences in health outcomes for various groups (Perry, King-Schultz, Aftab, and Bryant 2007; Casas, Dachs, and Bambas 2005; Dachs, Ferrer, Florez, Barros, 
Narvaez and Valdivia 2002; Pramparo, Montano, Barcelo, Avezum, and Wilks 2006). On one hand, researchers lament the emphasis on philosophic and theoretical treaties rather than on empirical treatment of health issues. Empirical studies when available are regarded as deficient because of data quality and other internal validity problems (Casas et al. 2005). On the other, there are those who laud the efforts in the region while at the same time supporting the limitations by identifying 112 conceptual studies or position papers; 43 macro-content analyses; 14 case studies; 44 aggregate ecological studies; and only 20 cross-sectional prevalence studies; 17 case-control cohort and 19 methodological studies (Almeida-Filho, Kawachi, Filho, and Dachs 2003).

Studies of inequality have ranged from a singular focus on income inequality (Gakidou, Murray, and Frenk, 2000) or poverty (AlmeidaFilho et al. 2003) to more elaborate multidimensional models that use more or less measures that underlie the physical, economic, institutional, local sociability and community organization context of people's lives (Bernard, Charafeddine, Frohlich, Daniel, Kestens and Potvin's 2007). Indeed, health disparity in the Caribbean is linked to extreme social inequalities, gender differences, poverty, education, access to health services and national origin (PAHO Strategic Plan 2003-2007; Pate, Collado, and Solis 2001; Pramparo, Montano, Barcelo, Avezum and Wilks 2006; Casas et al. 2005). A review of the available literature by Almeida-Filho et al. (2003) led to the conclusion however, that gender, race, and ethnic issues are often neglected in disparity research.

\section{Rationale for Studying Race and Health in Guyana}

The population of Guyana is diverse. As of the 2002 census the 751,223 population was comprised of $43.4 \%$ Indo-Guyanese; $30.2 \%$ Afro-Guyanese, $16.7 \%$ Mixed-Guyanese. The remaining $9.7 \%$ are mostly of Amerindians, with less than 1\% Chinese, Portuguese and other racial classifications. The racial division of the country by itself constitutes a reason for investigating the extent to which differences in health status may be influenced by race. It would be interesting to know whether patterns of health and illnesses vary across racial groups as a possible basis for medical intervention. Moreover, knowing such differences is an important first step in isolating the cultural and lifestyle factors that may be causally related to observed disparities in health status.

Research on racially differentiated societies has also moved beyond mere identification of the socio-economic differences in health outcomes to investigations of the social psychological nuances associated with socio-economic factors and social location variables. Racial diversity has a known potential for racial conflict and discrimination both real and 
perceived. This is particularly true if race is associated with inequitable or differential distribution of power and resources. Significant documentation is available to indicate that the psychological burdens associated with racism, segregation, discrimination and the like, have implications for health outcomes (Williams 1999; Williams, Neighbors and Jackson 2003; Williams and Collins 1995; 2001).

Guyana has had its share of racial tensions. Fueled mostly by racial politics which began in the 1960s, the situation in Guyana has fluctuated between outright racial violence to more recent charges of racial discrimination and statements of racial discord. Significant documentation is available on the racial and civic strife in Guyana during 1962-1964 (Halperin 1965; Premdas 1972; Mars 1995). While available data would not allow for an immediate examination of these issues empirically, the awareness of the potential negative impact of racial division and discord on the health of a multiracial society strengthens the case for studying race and health in Guyana.

Official statistics in Guyana provide little information on the racial profiles of health and illness. As an example, the Bureau of Statistics in Guyana routinely publishes mortality statistics as they vary by gender but rarely by racial groups. Table 1 presents such data as extracted and computed to show gender specific rates for leading causes of mortality in Guyana. These data indicate that females are almost twice more likely as men to die from diabetes mellitus, a difference consistent from 2002 through 2004 and a rate consistently higher than the national average. On the other hand, men averaged 3.3 times as many deaths from cirrhosis as women during the same period. Also, females are $2 \%$ more likely than men to die from ischemic and other heart problems in 2004, a pattern that varied from the two previous years. Similarly, rates of hypertensive deaths among females are consistently higher than among males in the general population.

While the data presented above are interesting, the picture is incomplete. Racial data would provide another level of information that may identify some of the important factors that account for differences in health status in Guyana. Additionally, data on racial differences in health status may have important policy implications for the delivery of health care in the country. Again, the documentation of such differences will be an important first step in isolating those contributing factors, thus fostering relevant and appropriate medical or social interventions.

Another compelling reason for race-based analyses in assessing health outcomes is the extent to which race matters in the presence of other predictive factors. It may be that such factors vary across racial groups and therefore have implications for the variation in health outcomes. Also, it would be important to document the unique contribu- 
Race and Health in Guyana

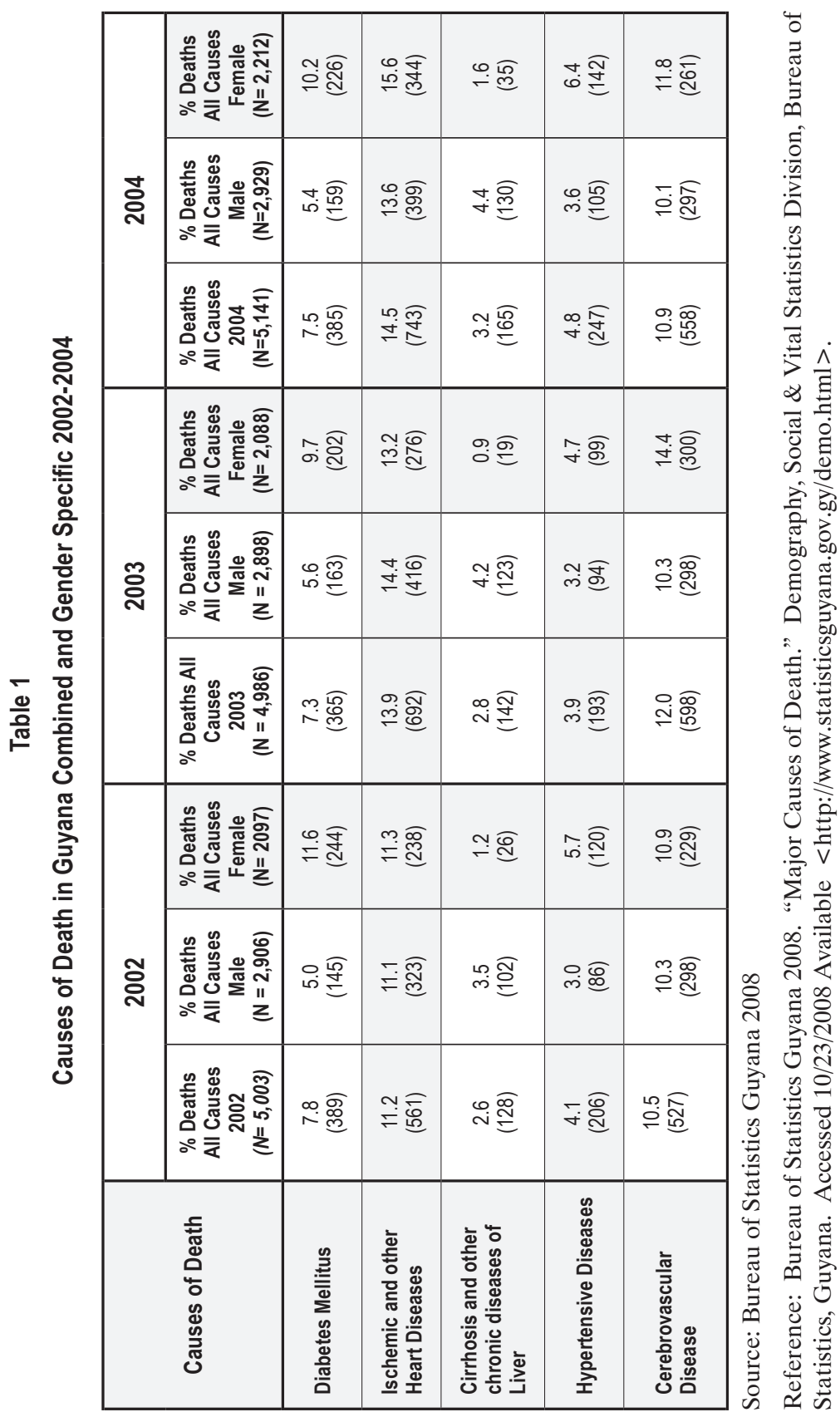


tion of race in health status over and beyond traditional indicators of SES. This is particularly salient within the perspective that proffers that physical and mental health outcomes may not operate similarly across racial groups.

These analyses in the paper explore the complex relationship that exists between race and health in different social contexts and across different measures of health status. Of particular importance is the interrelationship among physical health, mental well-being and socio-economic status and the age structure of the Guyanese sample. Two specific questions guide the analyses in this paper: what are the racial patterns of physical and mental health in Guyana? And, what influence does race have on the distribution of physical and mental health in Guyana when socio-economic and socio-demographic factors are controlled?

\section{Data and Measures}

We use survey data based on responses to face-to-face interviews administered to urban and rural heads of households and/or spouses/ partners of heads of households in Guyana. The data used in these analyses are derived from random three-stage samples of urban and rural Guyanese heads of household and/or their partners. The urban portion of the sample was drawn by the Bureau of Statistics, Guyana, and is representative of the Greater Georgetown population. The rural sample is based on a complete household listing of selected villages, and is representative of coastal dwellers in specific areas of Guyana and not the entire rural population of Guyana. A total of 923 respondents constitute the sample used in these analyses.

Several measures of physical health are used in this analysis: selfrated health; impairment due to health conditions; chronic illnesses, both lifetime and recent (one-year). Physical health was rated poor (1), fair (2), good (3) or excellent (4). Respondents were asked how much of the time their health impaired their daily routines and were offered responses ranging from (1) none of the time to (5) all of the time. Further, respondents reported on the number of chronic illnesses experienced during their lifetime, and if they had five specific health conditions during the last year.

To measure mental health conditions, we use the Center for Epidemiological Studies, Depression Subscale (CES-D) and a single item measure of life satisfaction. The CES-D scale is a summative score based on the responses from twenty-three questions on psychological symptoms experienced. Responses ranged from (0) rarely or none of the time to (3) most or all of the time. Respondents rated their life satisfaction from (1) not at all satisfied to (5) completely satisfied. The critical independent 
Table 2

Demographic Characteristics of Sample

\begin{tabular}{|l|c|c|c|}
\hline \multirow{2}{*}{ Variables } & \multicolumn{3}{c|}{ Percent } \\
\cline { 2 - 4 } & $\begin{array}{c}\text { Afro- } \\
\text { Guyanese }\end{array}$ & $\begin{array}{c}\text { Indo- } \\
\text { Guyanese }\end{array}$ & $\begin{array}{c}\text { Mixed/ } \\
\text { Other } \\
\text { Guyanese }\end{array}$ \\
\hline Average Age & 46.1 & 44.7 & 45.0 \\
\hline Median Age & 45.0 & 44.0 & 43.0 \\
\hline Percent with Primary education and below & 34.9 & 52.7 & 31.3 \\
\hline $\begin{array}{l}\text { Percent with Secondary/High school Level } \\
\text { Education }\end{array}$ & 44.0 & 39.0 & 46.0 \\
\hline $\begin{array}{l}\text { Percent with Above Secondary/High school } \\
\text { Level Education }\end{array}$ & 21.0 & 8.3 & 22.7 \\
\hline Percent Employed & 59.5 & 47.4 & 51.6 \\
\hline Percent in Nuclear households & 46.8 & 57.3 & 45.1 \\
\hline Percent in Single-Headed households & 28.4 & 14.0 & 27.4 \\
\hline Median Income & US \$215 & US \$200 & US \$217 \\
\hline Percent reporting high economic stress & 35.8 & 24.5 & 27.2 \\
\hline Median Household size & 4.6 & 3.7 & 4.5 \\
\hline
\end{tabular}

Source: Wilson (2004) Family Processes and Health in Guyana

variables used are: race (Indo-Guyanese, Afro-Guyanese and Mixed/ Other-Guyanese), gender, socio-economic status as measured by three levels of education: primary and below, secondary and post-secondary. The analyses we present are either age-specific or age-adjusted.

\section{Analysis and Results}

The results of a series of analyses are reported in this section. First, we present the age-specific gross estimates of the physical and mental well-being of the respondents. We then provide aspects of age-specific well-being taking the effect of educational level into account. Finally, we estimate parallel multivariate models that assess the simultaneous influences of several predictors of physical and mental well-being. 


\section{Age-Specific Measures of Physical Health}

In Table 3, we note important within age and across race differences in regards to physical health. For example, Indo-Guyanese are twice as likely to report fair or poor health, than both Afro and Mixed-Guyanese within the youngest age groups (19-29). The pattern is somewhat reversed for the other age groups, with Indo-Guyanese reporting slightly lower levels of fair and poor health than other racial groups for the cohorts of the forties and beyond. However, Indo-Guyanese in the 30-39 age group are almost twice less likely than Mixed-Guyanese to report poor or fair health. The difference between Indo-Guyanese and Afro-Guyanese for this age is negligible at less than two percent. Interestingly, and perhaps most critical, over half of all racial groups 50 years and above report just fair or poor health; with Afro-Guyanese doing so at a rate of about 5\% higher than the other racial groups. The findings here may not be inconsistent with the reality that life expectancy for Guyanese has not climbed beyond the 60s like several other English-speaking Caribbean countries.

Table 3

Age-Adjusted figures for General Health in Guyana by Race

\begin{tabular}{|l|r|r|r|r|r|r|r|r|r|r|r|r|}
\hline \multirow{2}{*}{\begin{tabular}{c} 
Response $\begin{array}{c}\text { Catego- } \\
\text { ries }\end{array}$ \\
\cline { 2 - 14 }
\end{tabular}} & \multicolumn{3}{|c|}{ 19-29 } & \multicolumn{3}{|c|}{$30-39$} & \multicolumn{3}{|c|}{$40-49$} & \multicolumn{3}{|c|}{50 and older } \\
\cline { 2 - 14 } & AG & IG & M/O & AG & IG & M/O & AG & IG & M/O & AG & IG & M/O \\
\hline Poor & 1.6 & 0.0 & 3.6 & 1.6 & 0.0 & 0.0 & 3.7 & 3.7 & 5.7 & 11.6 & 10.7 & 14.3 \\
\hline Fair & 11.1 & 25.8 & 7.1 & 10.6 & 8.7 & 16.7 & 30.3 & 26.8 & 28.6 & 45.5 & 41.7 & 37.5 \\
\hline Good & 44.4 & 38.7 & 50.0 & 36.6 & 47.8 & 44.4 & 35.7 & 41.5 & 17.1 & 27.0 & 36.9 & 35.7 \\
\hline Excellent & 42.9 & 35.5 & 39.3 & 51.2 & 43.5 & 38.9 & 30.3 & 28.0 & 48.6 & 15.9 & 10.7 & 12.5 \\
\hline Total & 100.0 & 100.0 & 100.0 & 100.0 & 100.0 & 100.0 & 100.0 & 100.0 & 100.0 & 100.0 & 100.0 & 100.0 \\
\hline
\end{tabular}

Source: Wilson (2004) Family Processes and Health in Guyana

$\mathrm{AG}=$ Afro-Guyanese

$\mathrm{IG}=$ Indo-Guyanese

$\mathrm{M} / \mathrm{O}=$ Mixed/Other Guyanese

In terms of impairment because of illness (Table 4), the pattern is that except for the 30-39 age group in which Mixed-Guyanese report the lowest levels of impairment, Indo-Guyanese report higher levels than all other racial groups. In fact, for the over 50 group, $18 \%$ of Indo- 
Table 4

Age-Adjusted figures for Health Impairments in Guyana by Race

\begin{tabular}{|c|c|c|c|c|c|c|c|c|c|c|c|c|}
\hline \multirow{3}{*}{$\begin{array}{l}\text { Response } \\
\text { Categories }\end{array}$} & \multicolumn{12}{|c|}{ Age by Race } \\
\hline & \multicolumn{3}{|c|}{$19-29$} & \multicolumn{3}{|c|}{$30-39$} & \multicolumn{3}{|c|}{$40-49$} & \multicolumn{3}{|c|}{50 and older } \\
\hline & AG & IG & $M / 0$ & AG & IG & $\mathrm{M} / \mathrm{O}$ & AG & IG & $\mathrm{M} / \mathrm{O}$ & AG & IG & $\mathrm{M} / 0$ \\
\hline $\begin{array}{l}\text { None of the } \\
\text { time }\end{array}$ & 67.2 & 67.7 & 67.8 & 74.0 & 69.1 & 75.0 & 76.8 & 63.7 & 62.9 & 51.1 & 44.6 & 63.6 \\
\hline $\begin{array}{l}\text { A little of the } \\
\text { time }\end{array}$ & 16.4 & 12.9 & 10.7 & 11.4 & 14.7 & 19.4 & 10.2 & 15.0 & 17.1 & 17.7 & 18.1 & 9.1 \\
\hline $\begin{array}{l}\text { Some of the } \\
\text { time }\end{array}$ & 9.8 & 9.7 & 17.9 & 5.7 & 13.2 & 5.6 & 10.2 & 13.8 & 17.1 & 19.9 & 19.3 & 18.2 \\
\hline $\begin{array}{l}\text { Most of the } \\
\text { time }\end{array}$ & 3.3 & 3.2 & 3.6 & 6.5 & 1.5 & 0.0 & 2.8 & 2.5 & 2.9 & 8.6 & 10.8 & 5.5 \\
\hline $\begin{array}{l}\text { All of the } \\
\text { time }\end{array}$ & 3.3 & 6.5 & 0.0 & 2.4 & 1.5 & 0.0 & 0.0 & 5.0 & 0.0 & 2.7 & 7.2 & 3.6 \\
\hline Total & 100.0 & 100.0 & 100.0 & 100.0 & 100.0 & 100.0 & 100.0 & 100.0 & 100.0 & 100.0 & 100.0 & 100.0 \\
\hline
\end{tabular}

Source: Wilson (2004) Family Processes and Health in Guyana

Guyanese, as opposed to $11.3 \%$ of Afro-Guyanese and $9.1 \%$ of MixedGuyanese reported that illness prevented their usual work most or all of the time. However, when juxtaposed with the fact that more than half of this age-group of all races report their general health as poor or fair, the picture may not have as serious implications for the productivity if this age-group is still in the workforce. Nonetheless, in terms of racial differences, Afro-Guyanese are $6 \%$ less likely to report at least some degree of impairment compared to the other racial groups. That almost a third of Afro-Guyanese and $37 \%$ of the other racial groups report some level of impairment, should be noteworthy for policy makers and those concerned with the needs of the elderly.

The age specific prevalence of chronic illness as shown in Table 5 provides a number of interesting patterns. First, these data are consistent with the expectations that the number of individuals reporting chronic illnesses across all races increases with the ages of the respondents. Regardless of age and race, high blood pressure/hypertension is the most frequently reported lifetime chronic illness except for asthmatic problems among Mixed-Guyanese between ages 30-39. For those 50 and over, as many as $46 \%$ of Indo-Guyanese, $45 \%$ of Mixed-Guyanese and $40 \%$ of Afro-Guyanese report hypertension. Except for the 30-39 agegroups, Indo-Guyanese have higher prevalence rates than other racial groups. Interestingly, these numbers may be showing up in the mortality statistics. In 2004, unlike the two previous years reported in Table 2, 
Table 5

Age-Adjusted Chronic Illnesses by Race

\begin{tabular}{|c|c|c|c|c|c|c|c|c|c|c|c|c|}
\hline \multirow{3}{*}{ Response Categories } & \multicolumn{12}{|c|}{ Age by Race } \\
\hline & \multicolumn{3}{|c|}{$19-29$} & \multicolumn{3}{|c|}{$30-39$} & \multicolumn{3}{|c|}{$40-49$} & \multicolumn{3}{|c|}{50 and older } \\
\hline & AG & IG & $\mathrm{M} / \mathrm{O}$ & AG & IG & $\mathrm{M} / \mathrm{O}$ & AG & IG & $\mathrm{M} / \mathrm{O}$ & AG & IG & $\mathrm{M} / \mathrm{O}$ \\
\hline $\begin{array}{l}\text { High Blood Pressure/ } \\
\text { Hypertension }\end{array}$ & 4.8 & 12.9 & 3.6 & 17.1 & 10.1 & 19.4 & 22.2 & 30.5 & 25.7 & 39.5 & 45.9 & 44.6 \\
\hline Stroke & 0.0 & 0.0 & 0.0 & 0.0 & 0.0 & 0.0 & 0.0 & 1.2 & 0.0 & 4.2 & 6.0 & 5.4 \\
\hline $\begin{array}{l}\text { Heart Attack or Heart } \\
\text { Problem }\end{array}$ & 0.0 & 0.0 & 0.0 & 2.4 & 0.0 & 0.0 & 2.8 & 2.5 & 2.9 & 7.9 & 11.9 & 10.7 \\
\hline $\begin{array}{l}\text { Diabetes, Sugar in Urine } \\
\text { or High Blood Sugar }\end{array}$ & 1.6 & 0.0 & 0.0 & 5.7 & 4.3 & 2.8 & 8.3 & 12.2 & 11.4 & 16.8 & 25.9 & 10.7 \\
\hline $\begin{array}{l}\text { Cancer or a Malignant } \\
\text { Tumor }\end{array}$ & 0.0 & 0.0 & 0.0 & 0.8 & 1.4 & 0.0 & 0.0 & 0.0 & 0.0 & 2.6 & 2.4 & 1.8 \\
\hline Arthritis or Rheumatism & 1.6 & 0.0 & 0.0 & 2.4 & 4.3 & 2.8 & 3.7 & 13.4 & 8.6 & 15.9 & 35.3 & 19.6 \\
\hline Stomach Ulcers & 3.2 & 0.0 & 3.6 & 4.1 & 5.8 & 5.6 & 3.7 & 11.0 & 5.7 & 4.8 & 15.3 & 3.6 \\
\hline Asthma & 3.2 & 6.5 & 7.1 & 5.7 & 4.3 & 2.8 & 2.8 & 1.2 & 14.3 & 1.6 & 6.0 & 3.6 \\
\hline $\begin{array}{l}\text { Cirrhosis, Liver Disease } \\
\text { or "Liver Trouble" }\end{array}$ & 0.0 & 0.0 & 0.0 & 0.0 & 1.4 & 2.8 & 0.9 & 1.2 & 0.0 & 1.1 & 4.8 & 0.0 \\
\hline $\begin{array}{l}\text { Kidney Problem or } \\
\text { "Kidney Trouble" }\end{array}$ & 3.2 & 0.0 & 10.7 & 1.6 & 0.0 & 8.6 & 1.8 & 3.7 & 8.6 & 1.6 & 1.2 & 3.6 \\
\hline $\begin{array}{l}\text { Chronic Bronchitis or } \\
\text { Emphysema }\end{array}$ & 0.0 & 0.0 & 0.0 & 0.8 & 0.0 & 0.0 & 0.9 & 0.0 & 5.7 & 2.1 & 2.4 & 8.9 \\
\hline Nervous Condition & 1.6 & 3.2 & 3.6 & 2.5 & 5.8 & 2.8 & 6.4 & 7.5 & 11.4 & 5.3 & 9.4 & 5.4 \\
\hline $\begin{array}{l}\text { Blood Circulation } \\
\text { Problem/Hardening of the } \\
\text { Arteries }\end{array}$ & 1.6 & 0.0 & 0.0 & 4.1 & 2.9 & 0.0 & 6.4 & 6.2 & 5.7 & 10.5 & 10.7 & 8.9 \\
\hline Sickle Cell Anemia & 1.6 & 0.0 & 0.0 & 0.0 & 0.0 & 0.0 & 1.8 & 0.0 & 0.0 & 0.5 & 1.2 & 0.0 \\
\hline High Cholesterol & 0.0 & 3.2 & 3.6 & 3.3 & 0.0 & 0.0 & 6.4 & 3.7 & 5.7 & 4.2 & 10.7 & 10.7 \\
\hline
\end{tabular}

Source: Wilson (2004) Family Processes and Health in Guyana

deaths from hypertensive diseases were among the five leading causes for the Guyanese population.

For those 40 and over, Indo-Guyanese also report higher prevalence of diabetes while for ages 30 and older, they report higher rates of arthritis or rheumatism. While the rates of those reporting stomach ulcers among racial groups are somewhat stable, the rates for IndoGuyanese increase significantly over time. Less than one percent of the respondents report such problems for the youngest age group, but the rates change to $5.8 \%$ for those between $30-39$, to $11 \%$ for those $40-49$, 
and $15.5 \%$ for those 50 and older. This means that for those 40 and older, Indo-Guyanese are three times more than Afro-Guyanese and 2.8 times more than Mixed-Guyanese to report stomach problems.

Analysis of more recent recurring illnesses reveals similar age patterns, though the racial differences are less distinctive except for a few conditions. Indo-Guyanese (32.3\%) between ages 19-29 report higher incidence of serious back problems than Afro (19\%) and Mixed-Guyanese $(17.9 \%)$. For the $30-39$ age group, the rates for Indo-Guyanese is slightly lower than the other racial groups, but the higher prevalence rates show up again for those 40 or older. Indo-Guyanese (16.1\%) between 19 and 29, report more frequent problems with breathing, as compared with Afro-Guyanese (6.3\%) and Mixed-Guyanese (10.7\%).

Table 6

Age-Adjusted Recent IIInesses by Race

\begin{tabular}{|l|r|r|r|r|r|r|r|r|r|r|r|r|}
\hline \multirow{3}{*}{ Response Categories } & \multicolumn{10}{|c|}{ Age by Race } \\
\cline { 2 - 14 } & \multicolumn{3}{|c|}{$19-29$} & \multicolumn{3}{|c|}{$30-39$} & \multicolumn{3}{|c|}{$40-49$} & \multicolumn{3}{|c|}{50 and older } \\
\cline { 2 - 14 } & AG & IG & M/O & AG & IG & M/O & AG & IG & M/O & AG & IG & M/O \\
\hline $\begin{array}{l}\text { Very bad headache or } \\
\text { migraines }\end{array}$ & 0.0 & 3.2 & 3.6 & 3.3 & 0.0 & 0.0 & 6.4 & 3.7 & 5.7 & 4.2 & 10.7 & 10.7 \\
\hline Problems with breathing & 6.3 & 16.1 & 10.7 & 13.8 & 7.2 & 5.6 & 9.2 & 15.9 & 17.1 & 9.0 & 12.9 & 19.6 \\
\hline $\begin{array}{l}\text { Serious hearing or vision } \\
\text { problems }\end{array}$ & 7.9 & 9.7 & 3.6 & 8.9 & 8.7 & 5.6 & 24.8 & 24.7 & 20.6 & 29.1 & 28.2 & 25.0 \\
\hline $\begin{array}{l}\text { Frequent minor or recurring } \\
\text { health conditions such as bad } \\
\text { allergies or infections }\end{array}$ & 7.9 & 12.9 & 7.1 & 8.1 & 3.0 & 5.6 & 5.5 & 7.4 & 0.0 & 6.3 & 3.6 & 10.7 \\
\hline Serious back problems & 19.0 & 32.3 & 17.9 & 21.3 & 19.1 & 22.2 & 18.5 & 26.8 & 22.9 & 20.6 & 27.1 & 17.9 \\
\hline
\end{tabular}

Source: Wilson (2004) Family Processes and Health in Guyana

\section{Age Specific Analysis of Mental Health}

Given the reports of the respondents to the survey, dissatisfaction with life circumstances would represent a major mental health problem in Guyana. About 64\% of Afro-Guyanese between the ages 19 and 29, $58 \%$ of Indo-Guyanese and three quarters of all Mixed-Guyanese in the same age group report extreme (not at all satisfied) dissatisfaction with their life circumstances. For the most part (the percent rating life satisfaction "not at all satisfied" dropped 9\% for Mixed-Guyanese, but increased again for the other age groups), the extreme negative rating of life satisfaction gets progressively worse in the older cohorts. When these figures are combined with those reporting "not very satisfied" the picture gets worse. Clearly, over $80 \%$ of the respondents in all age categories 
report some level of disaffection with their life circumstances. While this measure is consistently used to indicate a state of mental health, these relatively high incidents for all racial groups would seem to indicate that much more than a mere state of mind may be implicated in the assessment of this question by Guyanese respondents.

Table 7

Percent Distribution of Self-Reported Satisfaction with Life by Age and Race

\begin{tabular}{|c|c|c|c|c|c|c|c|c|c|c|c|c|}
\hline \multirow{3}{*}{$\begin{array}{l}\text { Response } \\
\text { Categories }\end{array}$} & \multicolumn{12}{|c|}{ Age by Race } \\
\hline & \multicolumn{3}{|c|}{$19-29$} & \multicolumn{3}{|c|}{$30-39$} & \multicolumn{3}{|c|}{$40-49$} & \multicolumn{3}{|c|}{50 and older } \\
\hline & AG & IG & $\mathrm{M} / \mathrm{O}$ & AG & IG & $\mathrm{M} / \mathrm{O}$ & AG & IG & $\mathrm{M} / \mathrm{O}$ & AG & IG & $\mathrm{M} / \mathrm{O}$ \\
\hline Not at all satisfied & 63.5 & 58.1 & 75.0 & 70.5 & 66.7 & 65.7 & 69.2 & 65.4 & 71.4 & 69.3 & 65.9 & 76.4 \\
\hline Not very satisfied & 12.7 & 22.6 & 7.1 & 11.5 & 11.6 & 25.7 & 14.0 & 18.5 & 11.4 & 11.1 & 14.1 & 16.4 \\
\hline Somewhat satisfied & 11.1 & 9.7 & 14.3 & 11.5 & 14.5 & 2.9 & 8.4 & 12.3 & 14.3 & 11.1 & 11.8 & 1.8 \\
\hline $\begin{array}{l}\text { Very/completely } \\
\text { satisfied }\end{array}$ & 12.7 & 9.7 & 3.6 & 6.6 & 7.2 & 5.7 & 8.4 & 3.7 & 2.9 & 8.5 & 8.2 & 5.5 \\
\hline
\end{tabular}

Source: Family Processes and Health in Guyana: Wilson, 2004

The Center for Epidemiological Studies Depression Subscale (CES-D) is a widely used measure of depressive symptoms in adults (Radloff 1977). The scale consists of 18 individual items and its econometric properties are well established and known. The summative scale used here has scores ranging from 0 to 54 with a mean of 13.1 and a standard deviation of 9.4 for this Guyanese sample. These figures indicate rather low overall reports of depressive symptoms in the Guyanese population. In fact, as many as $93 \%$ of the respondents report scores below the midpoint of the scale. In Table 8, we present the age-specific percentages of respondents falling within the interquartile ranges of the depression scores by race. The interquartile ranges in this case would represent those scoring six or below $(28.8 \%)$ on the depression scale, 7 to $12(23.1 \%), 13$ to $19(25.1 \%)$ and those scoring above 19.

The figures here indicate a similar pattern to what was observed for the physical health measures. Note that in Table 8, Indo-Guyanese, the least represented of the three groups among those respondents reporting the lowest levels of depression, (except for the 19-29 age group), are the most represented among the highest quartile of the distribution of depression scores. Note also, that Indo-Guyanese report the highest levels of depression scores for all age group of respondents between the median and the $75 \%$ percentile of the distribution of depression scores. 
Among the low depressive group, the scores are impressively different, with Indo-Guyanese represented as much as $19 \%$ lower than MixedGuyanese for the 19-29 age group, and 18\% lower than Afro-Guyanese. Equally impressive reverse differences are noted for the youngest groups of Guyanese in the sample, within the $50^{\text {th }}$ and $75^{\text {th }}$ percentile of the distribution of depression scores.

Table 8

Age Specific Percentages

for the Inter-quartile Range of Depression Scores by Race

\begin{tabular}{|c|c|c|c|c|c|c|c|c|c|c|c|c|}
\hline \multirow{3}{*}{$\begin{array}{c}\text { Inter- } \\
\text { Quartile } \\
\text { Range }\end{array}$} & \multicolumn{12}{|c|}{ Age by Race } \\
\hline & \multicolumn{3}{|c|}{$19-29$} & \multicolumn{3}{|c|}{$30-39$} & \multicolumn{3}{|c|}{$40-49$} & \multicolumn{3}{|c|}{50 and older } \\
\hline & AG & IG & $\mathrm{M} / \mathrm{O}$ & AG & IG & $M / O$ & AG & IG & $M / O$ & AG & IG & $M / O$ \\
\hline Low 25 & 27.4 & 13.3 & 32.1 & 35.0 & 23.5 & 27.8 & 24.8 & 20.7 & 38.3 & 38.9 & 20.7 & 25.0 \\
\hline $26-50$ & 21.0 & 26.7 & 25.0 & 19.5 & 20.6 & 30.6 & 27.5 & 15.9 & 17.6 & 22.1 & 22.0 & 28.6 \\
\hline $51-75$ & 27.4 & 43.3 & 14.3 & 22.7 & 29.4 & 27.7 & 25.7 & 31.7 & 23.5 & 23.2 & 24.4 & 21.4 \\
\hline High 25 & 24.2 & 16.7 & 28.6 & 22.8 & 26.5 & 13.9 & 22.0 & 31.7 & 20.6 & 15.8 & 32.9 & 25.0 \\
\hline Total & 100.0 & 100.0 & 100.0 & 100.0 & 100.0 & 100.0 & 100.0 & 100.0 & 100.0 & 100.0 & 100.0 & 100.0 \\
\hline
\end{tabular}

Source: Family Processes and Health in Guyana: Wilson, 2004

\section{SES Differences in Health}

The final set of analyses investigates possible differences in physical and mental health outcomes using education as an indicator of SES. Three categories of educational achievement were constructed to empirically represent the nature of the distribution of education in this sample: primary or below, secondary, and beyond secondary. To reduce the complexity of the analyses, we concentrate only on the extremes of the measures we use for physical and mental health. The objective is to assess the relative magnitude of the race differences relative to those attributable to SES.

In Table 9, we represent the race and educational differences for respondents who report poor or fair health. It is very clear that if we assess the differences between Afro and Indo-Guyanese, the race difference across the two groups remain, but the within group variations across educational levels are impressively higher than the across race variation (24.6/10.9 for AG and 13.7/10.9 for IG). The education variation for both Afro and Mixed-Guyanese seems less clear when we compare secondary and post-secondary graduates. The patterns are very similar for all other measures. Clearly then, the pattern of SES differences that we expect are apparent in these data at this level of analysis. 
Table 9

Total Percentage Reporting Poor or Fair Health by Race and Education Level

(Percent Poor Health in Parentheses)

\begin{tabular}{|l|c|c|c|}
\hline \multirow{2}{*}{ Education Level } & \multicolumn{3}{|c|}{ Race } \\
\cline { 2 - 4 } & Afro-Guyanese & Indo-Guyanese & $\begin{array}{c}\text { Mixed/Other } \\
\text { Guyanese }\end{array}$ \\
\hline \multirow{2}{*}{ Primary and Below } & 46.3 & 37.0 & 30.5 \\
& $(11.3)$ & $(8.7)$ & $(12.8)$ \\
\hline \multirow{2}{*}{ Secondary } & 21.7 & 23.3 & 23.1 \\
& $(2.5)$ & $(0.0)$ & $(7.2)$ \\
\hline \multirow{2}{*}{ Beyond Secondary } & 25.8 & 22.7 & 32.4 \\
& $(13.1)$ & $(0.0)$ & $(0.0)$ \\
\hline
\end{tabular}

Source: Family Processes and Health in Guyana: Wilson, 2004

\section{Logistic Regression Models}

We estimated a series of Logistic Regression (LR) models to assess the simultaneous effect of race, education (as a measure of SES), gender and age on physical and mental health outcomes. We appropriately dichotomized the indicators of physical and mental health as follows: self reported health: (1) excellent and good, (0) fair and poor; impairment: (1) some to all the time, (0) none or little of the time; chronic illnesses: (1) one or more chronic illnesses, (0) no chronic illness; recent illnesses: (1) one or more recent conditions, $(0)$ no recent illness; depression (1) depression score above 52.1, (0) depression score up to 52.1 (median split).

The results of the LR for the physical health measures are consistent in some cases and unexpected in others. First, and noticeably so, is that except for the Indo-Afro Guyanese difference to the extent they were impaired because of illness, no other race differences are apparent in these data once the other factors enter the equation. Clearly, physical health differences for the Guyanese sample are explainable by other variables. Gender, for example, significantly differentiates physical and mental health outcomes across all measures, though not in a consistent way. Men report poorer general health, though less impairment because of illness. However, men are $45 \%$ less likely to report one or more chronic illnesses, and $31 \%$ less likely to report recent recurring illnesses than women. In a similar way, men report lower levels of depression than women do, but unlike women report lower levels of life satisfaction. The gender difference in life satisfaction is significant only at the $90 \%$ $(\mathrm{p}=.10)$ confidence level. 
As expected, and for most of the indicators in our analysis, education significantly predicted the difference in health status of Guyanese adults. Except that education did not distinguish levels of impairment due to illness, the consistent pattern is that while those with higher levels of education tend to rate their general health status worse than those at the primary level or below, they do report less incidence of chronic or recent illnesses, lower levels of depressive symptomology, but higher levels of life satisfaction. Secondary educated respondents, when compared to those with primary education or less, are $36 \%$ less likely to report good or excellent health, but also about $30 \%$ less likely to report chronic or recent illnesses, and $43 \%$ less likely to report depression levels above the median of the sample. Respondents who are college educated are not statistically differentiated from primary educated respondents on all measures, but are impressively $39 \%$ less likely to report one or more chronic illnesses and $30 \%$ less likely to be in the "high" depression group.

Table 10

Coefficients, Standard Error, 2 Log-Likelihood, Pseudo R², And Odds Ratio for the Full Model

\begin{tabular}{|c|c|c|c|c|c|c|c|c|c|c|c|c|}
\hline \multirow[t]{2}{*}{ Variables } & \multicolumn{3}{|c|}{ Self-Reported Health } & \multicolumn{3}{|c|}{ Impairment } & \multicolumn{3}{|c|}{$\begin{array}{l}\text { Chronic } \\
\text { Illness }\end{array}$} & \multicolumn{3}{|c|}{$\begin{array}{l}\text { Recent } \\
\text { Illness }\end{array}$} \\
\hline & B & S.E. & Odds & B & S.E. & Odds & B & S.E. & Odds & B & S.E. & Odds \\
\hline $\begin{array}{l}\frac{\text { Race }}{\text { IndoGuy }} \\
\text { Mixed/Others } \\
\text { AfroGuy (omitted) }\end{array}$ & $\begin{array}{l}-.122 \\
-.103\end{array}$ & $\begin{array}{l}.182 \\
.218\end{array}$ & $\begin{array}{l}.885 \\
.902\end{array}$ & $\begin{array}{l}.311^{*} \\
-.110\end{array}$ & $\begin{array}{l}.191 \\
.239\end{array}$ & $\begin{array}{r}1.365 \\
.896\end{array}$ & $\begin{array}{r}-.086 \\
.145\end{array}$ & $\begin{array}{l}.170 \\
.203\end{array}$ & $\begin{array}{l}1.089 \\
1.157\end{array}$ & $\begin{array}{l}.124 \\
-.067\end{array}$ & $\begin{array}{l}.161 \\
.193\end{array}$ & $\begin{array}{r}1.132 \\
.935\end{array}$ \\
\hline $\begin{array}{l}\frac{\text { Gender }}{\text { Male }} \\
\text { Female (omitted) }\end{array}$ & $-.342^{* *}$ & .166 & .710 & $-.420^{* *}$ & .182 & .657 & $-.607^{\star *}$ & .156 & .545 & $-.374^{* *}$ & .147 & .688 \\
\hline $\begin{array}{l}\text { Education } \\
\text { Secondary } \\
\text { BeySec } \\
\text { Primary (omitted) }\end{array}$ & $\begin{array}{l}-.444^{\star \star} \\
-.212\end{array}$ & $\begin{array}{l}.189 \\
.212\end{array}$ & $\begin{array}{l}.642 \\
.809\end{array}$ & $\begin{array}{r}-.058 \\
.094\end{array}$ & $\begin{array}{l}.205 \\
.231\end{array}$ & $\begin{array}{l}1.059 \\
1.098\end{array}$ & $\begin{array}{l}-.385^{* *} \\
-.495^{* *}\end{array}$ & $\begin{array}{l}.176 \\
.204\end{array}$ & $\begin{array}{l}.681 \\
.610\end{array}$ & $\begin{array}{l}-.356^{* *} \\
-.100\end{array}$ & $\begin{array}{l}.170 \\
.192\end{array}$ & $\begin{array}{l}.700 \\
.905\end{array}$ \\
\hline Age & $-.058^{* *}$ & .006 & .943 & $.034^{* *}$ & .006 & 1.035 & $.054^{* *}$ & .006 & 1.055 & $.020^{* *}$ & .005 & 1.020 \\
\hline $\begin{array}{l}\text { 2LL } \\
\text { Pseudo R² }\end{array}$ & \multicolumn{3}{|c|}{$\begin{array}{c}994.703^{a} \\
.219\end{array}$} & \multicolumn{3}{|c|}{$\begin{array}{c}894.564 a \\
.046\end{array}$} & \multicolumn{3}{|c|}{$\begin{array}{c}1097.953 a \\
.207\end{array}$} & \multicolumn{3}{|c|}{$\begin{array}{c}1193.0298 \mathrm{a} \\
.055\end{array}$} \\
\hline
\end{tabular}

** Significant $(\mathrm{p}=.01) ; *$ Significant $(\mathrm{p}=.05)$.

AfroGuy $=$ Guyanese of African descent

IndoGuy - Guyanese of Indian descent

BeySec $=$ Above secondary level education 
Finally, while age differences in health outcomes are consistent for physical illnesses, the effect on mental health is less impressive. As expected, older respondents report poorer general health and higher levels of impairment as a result of illnesses. They are also significantly more likely to report one or more chronic and recent illnesses when compared to younger respondents. Age does not differentiate levels of life satisfaction, and only significantly distinguish between levels of depression if the probability level of evaluation is set at .10 .

Table 11

Logistic Regression Results for Socio-Demographic and Socio-Economic Predictors of Mental Health Outcomes

\begin{tabular}{|c|c|c|c|c|c|c|}
\hline \multirow{2}{*}{ Variable } & \multicolumn{3}{|c|}{ Life Satisfaction } & \multicolumn{3}{|c|}{ Depression } \\
\hline & B & SE & Odds & B & SE & Odds \\
\hline $\begin{array}{l}\text { Race } \\
\text { IndoGuyanese } \\
\text { Mixed/Others } \\
\text { AfroGuy (omitted) }\end{array}$ & $\begin{array}{l}.460^{* *} \\
-.209\end{array}$ & $\begin{array}{l}.178 \\
.198\end{array}$ & $\begin{array}{r}1.583 \\
.811\end{array}$ & $\begin{array}{l}.752^{* \star} \\
-.043\end{array}$ & $\begin{array}{l}.171 \\
.202\end{array}$ & $\begin{array}{r}2.121 \\
.958\end{array}$ \\
\hline $\begin{array}{l}\text { Gender } \\
\text { Male } \\
\text { Female (omitted) }\end{array}$ & $-.277^{* *}$ & .154 & .758 & $-.507^{* *}$ & .155 & .605 \\
\hline $\begin{array}{l}\text { Education } \\
\text { Secondary } \\
\text { Beyond Sec. } \\
\text { Primary (omitted) }\end{array}$ & $\begin{array}{l}.266^{*} \\
.551\end{array}$ & $\begin{array}{l}.181 \\
.211\end{array}$ & $\begin{array}{l}1.305 \\
1.735\end{array}$ & $\begin{array}{l}-.562^{* *} \\
-.357^{*}\end{array}$ & $\begin{array}{l}.181 \\
.203\end{array}$ & $\begin{array}{l}.570 \\
.700\end{array}$ \\
\hline Age & -002 & .006 & .998 & $-.008^{*}$ & .005 & .992 \\
\hline $\begin{array}{l}2 \mathrm{LL} \\
\text { Pseudo } \mathrm{R}^{2}\end{array}$ & \multicolumn{3}{|c|}{$\begin{array}{c}1083.584^{\mathrm{a}} \\
.028\end{array}$} & \multicolumn{3}{|c|}{$\begin{array}{c}1075.938^{\mathrm{a}} \\
.075\end{array}$} \\
\hline
\end{tabular}

** Significant $(p=.01) ;{ }^{*}$ Significant $(p=.05)$.

\section{Discussion and Conclusions}

This paper reports significant findings about age-specific racial differences in physical and mental health in Guyana. Clearly, the within age-group analyses revealed some interesting patterns by race, but there are no compelling racial differences in self-reported health once other factors such as gender, educational level and age are controlled. Except that Indo-Guyanese report significantly higher levels of impairment as compared to Afro-Guyanese, racial differences in physical health are attenuated when all the variables used in this analysis are considered simultaneously.

The absence of racial differences does not however negate the racial 
differences observed for specific chronic and recent illnesses. The results of the combined models for these two indicators of physical health must be understood in the context of the limitations of the data we present and as a result the nature of the analysis undertaken. The analysis of specific illnesses earlier, which indicated higher rates of hypertension among most age-groups of Indo-Guyanese, as well as higher incidence of diabetes, arthritis or rheumatism, back and breathing problems are interesting and should engage the attention of health providers. Nonetheless, the prevalence rates of the specific health problems were too small and did not allow for disaggregated analyses of these problems. Accordingly, the final logistic models we present assessed racial differences in the number of chronic and recent recurring illnesses, and there is where we find the absence of consistent racial differences. Our findings, therefore, are useful in that further research must isolate specific illnesses and attempt to undercover reasons for the differences observed and reported in this paper.

These data reported here do provide other rich and interesting insight on health based on other critical variables. The gender patterns of health for this population are noteworthy. Men's subjective rating of their general health status is poorer than women, but they report fewer incidences of chronic illnesses and recurring health problems than women. We submit that men's appraisal of their general state of health may be a more accurate picture of the reality, given the reluctance of men to avail themselves of medical services except when seriously ill. It may be then, that the differences in the reported levels of chronic illnesses result from a greater awareness of their health condition on the part of women who use the healthcare system more systematically than men do. In terms of the mental health, we suggest, as previously reported, that women's greater involvement in caring roles, and as such greater awareness and concern for the plight of others, may explain some of the differences observed, and we note the relatively lower levels of depression for the population as a whole. Women's more positive assessment of their life circumstances, however, is perhaps their greater ability to cope with the exigencies of everyday problems in a depressed economy as compared to men.

The SES differences are consistent with our expectations, except in the case of self-reported health. These data suggest that while the assessment of general health was inversely related to educational attainment, the objective measures of health status had the opposite expected effect. As we noted earlier, respondents with higher levels of education reported lower levels of general health, but less problems with both chronic and recent illnesses as well as lower levels of depression. We do not find a persuasive explanation for this finding, but offer that respondents with 
higher levels of education may be much more aware of the consequences of diagnosed health problems, and this may result in harsher judgment of their general health status. On the other hand, it may be that the collective struggle of poverty and deprivation forges a greater appreciation of any measure of health, and thus a more salutary appraisal of health.

\section{References}

Almeida-Filho, N.A., I. Kawachi, A.P. Filho and J.N.W. Dachs. 2003. "Research on Health Inequalities in Latin America and the Caribbean: Bibliometric Analysis (1971-2000) and Descriptive Content Analysis (1971-1995)." American Journal of Public Health 93:2037-2043.

Bernard, P., R. Charafeddine, K.L. Frohlich, M. Daniel, Y. Kestens and L. Potvin. 2007. "Health Inequalities and Place: A Theoretical Conception of Neighborhood." Social Science and Medicine 65:1839-1852.

Braithwaite, R.L. and S. Taylor. 2001. Health Issues in the Black Community. $2^{\mathrm{d}}$ ed. San Francisco: Jossey-Bass.

Carter-Pokras, Olivia and Claudia Baquet. 2002. "What is a "Health Disparity"?" Public Health Reports 117 (5):426-434.

Bureau of Statistics Guyana. 2008. "Major Causes of Death.” Demography, Social \& Vital Statistics Division, Bureau of Statistics, Guyana. Accessed 10/23/2008. Available < http://www.statisticsguyana.gov.gy/demo.html>.

Casas, J.A., J.N.W. Dachs and A. Bambas. 2005. Health Disparities in Latin America and the Caribbean: The Role of Social and Economic Determinants. Washington, DC: Pan American Health Organization.

Dachs, J.N.W., M. Ferrer, M., Florez, C.A., A.J.D. Barros, R. Narvaez and M. Valdivia. 2002. "Inequalities in Health in Latin America and the Caribbean: Descriptive and Exploratory Results for Self-reported Health Problems and Health Care in Twelve Countries." Pan American Journal of Public Health, pp. 335-355.

Fiscella, K. and D.R. Williams 2004. "Health Disparities Based on Socioeconomic Inequities: Implications for Urban Health Care. Academy Med. 79:1139-1147.

Gakidou, E.E., C.J.L. Murray and J. Frenk. 2000. "Defining and Measuring Health Inequality: An Approach Based on the Distribution of Health Expectancy." Bulletin of the World Health Organization 78:42-54.

Halperin, E. 1965. "Racism and Communism in British Guiana." Journal of Inter-American Studies 7:95-134.

Krieger, N. 1987. "Shades of Difference: Theoretical Underpinnings of the Medical Controversy on Black/Whites Differences in the United States, 1830-1870." International Journal of Health Services 17:259-78. 
LaVeist, T.A. 2000. "African Americans and Health Policy: Strategies for a Multiethnic Society." Pp. 145-161 in New Directions: African Americans in a Diversifying Nation, edited by J.S. Jackson. Washington, DC: National Policy Association.

Mars, P. 1995. "State Intervention and Ethnic Conflict Resolution: Guyana and the Caribbean Experience." Comparative Politics 27:167-186.

Neighbors, H.W. and D.R. Williams. 2001. "The Epidemiology of Mental Disorder 1985 to 2000." Pp. 99-128 in Health Issues in the Black Community, $2 \mathrm{~d}$ ed., edited by R.L. Brathwaite and S. Taylor. San Francisco: Jossey-Bass.

Pan American Health Organization. 2005. PAHO Strategic Plan 2004-2007- Midterm Assessment - Priority countries. Accessed 11/7/2007. < http://www.paho. org/english/d/csu/PriorityCountries-eng.pdf > .

Pate, E., C. Collado and J.A. Solis. 2001. Health Equity and Maternal Mortality. Washington, DC: PAHO Publications.

Perry, H.B., L.W. King-Schultz, A.S. Aftab and J.H. Byrant. 2007. "Health Equity Issues at the Local Level: Socio-geography, Access, and Health Outcomes in the Service Area of the Hôpital Albert Schweitzer-Haiti." International Journal for Equity in Health 6:1-10.

Pramparo, P., C.M. Montano, A. Barceló, A. Avezum and R. Wilks. 2006. "Cardiovascular Diseases in Latin America and the Caribbean: The Present Situation." Prevention and Control 2:149-157.

Premdas, R.A. 1972. "Elections and Political Campaigns in a Racially Bifurcated State: The Case of Guyana." Journal of Interamerican Studies and World Affairs 14: 271-296.

Radloff, Lenore, S. 1977. "The CES-D Scale: A Self-Report Depression Scale for Research in General Population." Applied Psychological Measurement 1 (3):385-401.

Rathore, S.S. and H.M. Krumholz. 2004. "Differences, Disparities, and Biases: Clarifying Racial Variations in Health Care Use." Annals of Internal Medicine 141 (8):635-638

Williams, D.R. and C. Collins. 1995. "U.S. Socioeconomic and Racial Differences in Health: Patterns and Explanations." Annual Review of Sociology 21:349-86.

2001. "Racial Residential Segregation: A Fundamental Cause of Racial Disparities in Health." Public Health Reports 116 (5):404-16.

Williams, D.R., R. Lavizzo-Mourey and R. Warren. 1994. "The Concept of Race and Health Status in America." Public Health Reports 109:126-41.

H.W. Neighbors and J.S. Jackson. "Racial/Ethnic Discrimination and Health: Findings from Community Studies." American Journal of Public Health 93 (2):200-208.

Y. Yan, J.S. Jackson, and N. Anderson. 1997. "Racial Differences in Physical and Mental Health: Socio-economic Status, Stress, and Discrimination." Journal of Health Psychology 2 (3):335-51. 
58 LEON C. WILSON, COLWICK M. WILSON, BRIDGETTE M. JOHNSON

Wilson, C. and D.R. Williams. 2004. "African American Mental Health." Pp. 369-382 in Handbook of Black American Health (2 $2^{\text {nd }}$ Edition): Policies and Issues Behind Disparities in Health. Westport, CT: Greenwood Press. 